\title{
Trace Elements and Their Significance in the Postnatal Development of Seasonal Generations of the Bank Vole
}

\author{
Elżbieta MALZAHN
}

\begin{abstract}
Malzahn E., 1981: Trace elements and their significance in the postnatal development of seasonal generations of the bank vole. Acta theriol., 26, 13: 231-256 [With 5 Tables \& 6 Figs.].

Examination was made of concentrations of 10 trace elements ( $F e$, $\mathrm{Zn}, \mathrm{Co}, \mathrm{Se}, \mathrm{Sb}, \mathrm{Eu}, \mathrm{Cr}, \mathrm{Hg}, \mathrm{Sc}$ and $\mathrm{Ce}$ ) in the liver, kidneys and heart of the bank vole, Clethrionomys glareolus (Schreber, 1780), in individuals of the spring and autumn generations, during the postnatal development of these animals ( $1-60$ days). Two types of elements were distinguished, differing in respect of contents in the dry mass of organs from voles of the generations compared, but of the same age. Elements belonging to type $\mathrm{I}(\mathrm{Fe}, \mathrm{Co}, \mathrm{Sc}, \mathrm{Sb}, \mathrm{Se})$ are found in greater amounts in voles of the autumn generation than in those of the spring, but type II elements ( $\mathrm{Eu}, \mathrm{Zn}, \mathrm{Cr}$ ) occur in greater amounts in voles of the spring than of the autumn generation, in each age group. Maximum concentrations of trace elements occur in the organs of day-old or 10-day old voles, after which they decrease up to the 20th day of the animals' life, parallel to changes in the oxidation-reduction activity changes in the shrews' organs. At a later age oxidation-reduction activity in voles undergoes further decrease in each organ, until the low level characteristic of the organs of adult voles is reached and maintained up to the 90th-120th day of the animals' life. Voles of the spring generation have a higher level of organ activity after birth, but the low level of this activity is reached more rapidly than in voles of the autumn generation. Inorganic substances were found to affect maintenance of the appropriate level of oxidation-reduction activity in the voles' organs during postnatal development.
\end{abstract}

[Mammals Res. Inst., Polish Acad. Sci., 17-230 Białowieża, Poland]

\section{INTRODUCTION}

Trace elements, as essential components of numerous metabolically active compounds in the organism, play and active part in regulation of indirect metabolism. The participation of elements in the biological processes necessary to life results from their basic action on cell activity (Maugh, 1973; Davies, 1977), the most important function of elements being their activity in the majority of enzymatic systems. Activator elements are important for the whole of metabolic processes and also inhibitors of different processes. It must be emphasised that interactions take place between trace elements, in consequence of which it is not 
always possible to distinguish between their functions. Hence information on the occurrence at the same time of the greatest possible number of elements in living organisms is of importance.

Even though the amount of information on the effect on organisms of deficiency or presence of different trace elements (see Underwood, 1971 ) is abundant, it has still proved impossible exactly to establish the contents of these elements in organs and organic fluids in animals, which could then serve as a criterion when defining the animals' requirements for different trace elements.

The bank vole, Clethrionomys glareolus (Schreber, 1780) is generally regarded as an interesting object of research, on account of the wide range of its occurrence and the relatively well-documented biology of this species of small mammal. During the first month of life bank voles are characterized by very intensive increase in body weight and rapid development of physiological functions, so that at the age of four weeks young individuals are completely ready for an independent way of life (Sviridenko, 1959). The rate of postnatal development depends, however, on the season in which the young animals are born. Individuals from different seasonal generations differ from each other as to the rate at which they attain sexual maturity, fecundity and ecological length of life.

In order to analyze physiological differences in rate of growth and development in voles of different seasonal generations it was decided to examine the contents of trace elements in metabolically active organs from voles of the spring and autumn generations during the first two months of their lives. On account of the varied role of elements in metabolic processes a search was made for an index which would reflect the simultaneous action of a large number of elements. The oxidation-reduction activity of organs, treated as the resultant of the action of diverse metabolically active substances, differing as to the degree in which they were engaged in oxidation-reduction processes taking place in vole organs during the postnatal development of these animals, was taken as this index.

\section{MATERIAL AND METHODS}

Adult sexually mature voles treated as the parent generation, were caught in the Białowieża National Park in the spring and autumn of 1975 and 1976. The animals were kept in captivity in the Mammals Research Institute of the Polish Academy of Sciences at Białowieża until progeny were obtained (10-40 days). The first generation of these voles used for the studies were taken from their mothers 20 days after birth and each individual was kept separately. The voles were fed on oat grains, beet and carrot, and provided with water ad libitum. 
Voles born during the period from April to June (spring generation) and from September to December (autumn generation) from 1, 10, 20, 30 to 60 days old, were used for the experiments. Additional studies were made of voles 90 and 120 days old in respect of the oxidation-reduction activity of their organs. A total of 456 individuals were used in the experiments (256 from the spring generation and 198 from the autumn generation).

The animals were anaesthetized with ether, after which the liver, kidneys and heart were excised. The organs were washed in distilled water, dried on filter paper and weighed. Further preparation of the organs for analysis depended on the study methods.

The method of instrumental neutron activation analysis (INAA) was chosen for examining the contents of trace elements in the organs, as it permitted of simultaneous identification of up to $30-40$ elements. This method is highly sensitive and only requires physical adaptation of samples to neutron irradiation and measurements of induced radioactivity, but does not require chemical processing, which limits the risk of contamination of the samples (Jakutowicz, 1973). Preparation of the organ samples consisted in drying each organ at a temperature of $105^{\circ} \mathrm{C}$, weighing the dry mass and then pulverisation and trituration in an agate mortar. On account of the large number of samples and the extremely small weight of some of the samples, particularly of the organs of day-old voles, individual identification was not carried out, but the dry mass of the organs of all voles of uniform age were combined - on the 1,10,20,30 and 60 day of life of the animals, i.e. during the period in which the percentage of mineral substances increases in the structure of the fat-free body mass of voles (Fedyk, 1974). Samples were taken from the

Table 1

Nuclear data for trace elements determined in bank voles.

\begin{tabular}{|c|c|c|c|c|c|}
\hline $\begin{array}{c}\text { Element } \\
\text { cetermined }\end{array}$ & $\begin{array}{l}\text { Nuclide } \\
\text { irradiated } \\
\text { (target) }\end{array}$ & $\begin{array}{l}\text { Nuclide } \\
\text { counted }\end{array}$ & $\begin{array}{c}\text { Analytical } \\
\text { peak } \\
(\mathrm{E} \gamma-\mathrm{keV})\end{array}$ & $\begin{array}{l}\text { Neutron (thermal) } \\
\text { cross section } \\
\left(\delta_{\text {th }}-\text { barns }\right. \\
\left.\left.\times 10^{-24} \mathrm{~cm}^{2}\right)\right)\end{array}$ & $\begin{array}{c}\text { Half-time of } \\
\text { radionuclide } \\
\mathrm{T}_{1 \mathrm{v} 2}\end{array}$ \\
\hline Iron & ${ }^{58} \mathrm{Fe}$ & $\mathrm{Fe}^{59}$ & 1099.3 & 1.23 & 44.6 days \\
\hline Zinc & ${ }^{64} \mathrm{Zn}$ & $\mathrm{Zn}^{65}$ & 1115.5 & 0.82 & 243.8 days \\
\hline Cobalt & ${ }^{58} \mathrm{Co}$ & $\mathrm{Co}^{80}$ & $1173 ; 1332$ & 37.0 & 5.3 years \\
\hline Selenium & ${ }^{74} \mathrm{Se}$ & $\mathrm{Se}^{75}$ & $136 ; 264.5$ & 30.0 & 120 years \\
\hline Antimony & ${ }^{123} \mathrm{Sb}$ & $\mathrm{Sb}^{\mathrm{A24}}$ & 1690 & 3.45 & 60.3 days \\
\hline \multirow{2}{*}{ Europium } & ${ }^{151} \mathrm{Eu}$ & $\mathrm{Eu}^{152}$ & 344 & 3100 & 12.4 years \\
\hline & ${ }^{153} \mathrm{Eu}$ & Eu ${ }^{154}$ & 1408 & 154 & 16 years \\
\hline Chromium & ${ }^{50} \mathrm{Cr}$ & $\mathrm{Cr}^{51}$ & $32 \mid 0.1$ & 16.0 & 27.8 days \\
\hline Mercury & ${ }^{202} \mathrm{Hg}$ & $\lg ^{203}$ & $82.5 ; 279.2$ & 4.9 & 46.6 days \\
\hline Scandium & ${ }^{45} \mathrm{Sc}$ & $\mathrm{Sc}^{46}$ & 889 & $i 23$ & 84 days \\
\hline Cerium & ${ }^{140} \mathrm{Ce}$ & $\mathrm{Ce}^{141}$ & 145.5 & 0.54 & 32.4 days \\
\hline
\end{tabular}

pulverised dry mass of the different organs, obtaining an average by mixing the combined dry mass of organs weighing from 10 to $250 \mathrm{mg}$, then placing them in polythene bags and subjecting them, together with simultaneously prepared quantitative models of the elements, to radiation for a period of 105 hours in the FWA nuclear reactor (Swierk) in a stream of thermic neutrons (1-5).1012 $\mathrm{n} / \mathrm{cm}^{2} \mathrm{~s}$. The irradiated packet of samples and models were cooled and taken for measurements after a lapse of 20 to 60 days. The nuclear properties of the identified nuclides are given in table 1. Analysis of the gamma-ray spectrum was carried 
out by means of a semi-conductor detector $(\mathrm{Ge} / \mathrm{Li})$. The precision of determination was calculated as the radiometric counting error of the net peak area. Results of identifications have been given in the form of concentrations, i.e. $\mu \mathrm{g} / \mathrm{g}$ dry mass $(\mathrm{ppm})$ and in the form of contents $(\mu \mathrm{g})$ in the total mean dry mass of one vole organ in the different age groups.

Oxidation-reduction activity of the organs was determined by the chemiluminescence method (Malzahn, 1978). Weak chemiluminescence $(C H L)$ of the pyrogallol uxidation reaction by hydrogen peroxide was used as a basis. An addition of $0.1 \mathrm{ml}$ of tissue homogenate was made to this model reaction of known course. The homogenate was obtained by homogenizing whole organs with the addition of Krebs-Ringer solution ( $\mathrm{pH} 7.4)$, in parts of $0.5 \mathrm{ml}$ of solution to each $100 \mathrm{mg}$ of the fresh mass of tissue. The totalled number of impulses obtained from calculations of the electron counter from the time of adding the homogenate to the model reaction up to the time that reaction ended, was treated as the oxidationreduction activity of the given organ. The oxidation-reduction activity of vole organs was determined in the same age groups in which occurrence of trace elements had been examined, and also at the age of 90 and 120 days, in order to determine whether the activity level of the organs changes as the animals grow older.

In experiments in which oxidation-reduction activity was blocked, addition was made to the homogenates of water solutions of $\mathrm{KCN}$ and $\mathrm{NaN}_{3}$ at concentrations of $1 \times 10^{-3} \mathrm{M}$ and $1 \times 10^{-4} \mathrm{M}$. The addition of blocking substances to the Krebs-Ringer solution itself, in volume identical to that of the homogenate, did not cause changes in the level of photon emission of the model reaction. Proteins in the homogenates were denaturated by keeping homogenates in boiling water for 5 minutes before measurement.

The results obtained were analyzed statistically, using the Student $t$ test, and variance analysis with the new multiple range test. Coefficients of correlation and regression equation were calculated between oxidation-reduction activity and weight of organs during the postnatal development of the voles.

\section{RESULTS}

During the period of the postnatal development of the study voles the absolute weight and dry mass of their organs increased ('lable 2). Both generations of voles in the majority of the age groups failed to differ to a statistically significant extent in respect of these organ indices.

Table 2

Absolute organ weights (mg) (a) and dry mass (mg) (b) of voles of different generations during postnatal development. NS=differences between generations not significant, S - differences between generations statistically significant with $P>.01$ (Student $t$ test).

\begin{tabular}{|c|c|c|c|c|c|c|c|c|}
\hline \multirow{2}{*}{$\begin{array}{l}\text { Age, } \\
\text { days }\end{array}$} & & \multicolumn{3}{|c|}{ Spring generation } & \multicolumn{3}{|c|}{ Autumn generation } & \multirow{2}{*}{$\begin{array}{l}\text { Diff. } \\
\text {. }\end{array}$} \\
\hline & & $\mathrm{N}$ & $\overline{\mathrm{x}} \pm$ S.D. & (CV) & $\mathrm{N}$ & $\overline{\mathrm{x}} \pm$ S.D. & $(\mathrm{CV})$ & \\
\hline \multicolumn{9}{|c|}{ Liver } \\
\hline 1 & $\begin{array}{l}\text { a) } \\
\text { b) }\end{array}$ & $\begin{array}{l}44 \\
24\end{array}$ & $\begin{array}{c}127 \pm 35 \\
18.2 \pm 3.0\end{array}$ & $\begin{array}{l}(27.3) \\
(16.5)\end{array}$ & $\begin{array}{l}31 \\
18\end{array}$ & $\begin{array}{c}135 \pm 35 \\
18.4 \pm 2.7\end{array}$ & $\begin{array}{l}(24.6) \\
(14.9)\end{array}$ & $\begin{array}{l}\text { NS } \\
\text { NS }\end{array}$ \\
\hline
\end{tabular}




\begin{tabular}{|c|c|c|c|c|c|c|c|c|}
\hline 10 & $\begin{array}{l}\text { a) } \\
\text { b) }\end{array}$ & $\begin{array}{l}45 \\
27\end{array}$ & $\begin{array}{c}212 \pm 39 \\
32.4 \pm 7.0\end{array}$ & $\begin{array}{l}(18.3) \\
(21.6)\end{array}$ & $\begin{array}{l}31 \\
16\end{array}$ & $\begin{array}{c}224 \pm 47 \\
40.8 \pm 4.8\end{array}$ & $\begin{array}{l}(20.9) \\
(11.8)\end{array}$ & $\begin{array}{r}\text { NS } \\
\text { S }\end{array}$ \\
\hline 20 & $\begin{array}{l}\text { a) } \\
\text { b) }\end{array}$ & $\begin{array}{l}38 \\
23\end{array}$ & $\begin{array}{c}612 \pm 107 \\
123.1 \pm 20.6\end{array}$ & $\begin{array}{l}(17.6) \\
(16.6)\end{array}$ & $\begin{array}{l}29 \\
14\end{array}$ & $\begin{array}{c}713 \pm 167 \\
184.9 \pm 35.6\end{array}$ & $\begin{array}{l}(23.4) \\
(19.3)\end{array}$ & $\stackrel{\text { NS }}{\mathrm{S}}$ \\
\hline 30 & $\begin{array}{l}\text { a) } \\
\text { b) }\end{array}$ & $\begin{array}{l}41 \\
23\end{array}$ & $\begin{array}{c}762 \pm 148 \\
147.7 \pm 32.1\end{array}$ & $\begin{array}{l}(19.5) \\
(21.7)\end{array}$ & $\begin{array}{l}34 \\
14\end{array}$ & $\begin{array}{c}840 \pm 35 \\
200.3 \pm 31.8\end{array}$ & $\begin{array}{l}(18.3) \\
(22.7)\end{array}$ & $\begin{array}{r}\mathrm{NS} \\
\mathrm{S}\end{array}$ \\
\hline 60 & $\begin{array}{l}\text { a) } \\
\text { b) }\end{array}$ & $\begin{array}{l}39 \\
20\end{array}$ & $\begin{array}{c}979 \pm 211 \\
216.3 \pm 48.5\end{array}$ & $\begin{array}{l}(21.5) \\
(22.4)\end{array}$ & $\begin{array}{l}28 \\
13\end{array}$ & $\begin{array}{c}1070 \pm 218 \\
253.1 \pm 52.5\end{array}$ & $\begin{array}{l}(20.3) \\
(20.7)\end{array}$ & $\begin{array}{l}\text { NS } \\
\text { NS }\end{array}$ \\
\hline 90 & a) & 19 & $1044 \pm 347$ & $(33.3)$ & 15 & $1021 \pm 336$ & $(32.9)$ & NS \\
\hline 120 & a) & 16 & $1065 \pm 264$ & $(24.8)$ & 15 & $1124 \pm 243$ & $(21.6)$ & NS \\
\hline \multicolumn{9}{|c|}{ Kidneys } \\
\hline 1 & $\begin{array}{l}\text { a) } \\
\text { b) }\end{array}$ & $\begin{array}{l}42 \\
24\end{array}$ & $\begin{array}{c}36 \pm 12 \\
3.1 \pm 1.1\end{array}$ & $\begin{array}{l}(34.4) \\
(35.7)\end{array}$ & $\begin{array}{l}31 \\
18\end{array}$ & $\begin{array}{c}35 \pm 11 \\
2.2 \pm 0.8\end{array}$ & $\begin{array}{l}(31.1) \\
(35.8)\end{array}$ & $\begin{array}{r}\mathrm{NS} \\
\mathrm{S}\end{array}$ \\
\hline 10 & $\begin{array}{l}\text { a) } \\
\text { b) }\end{array}$ & $\begin{array}{l}45 \\
27\end{array}$ & $\begin{array}{r}84 \pm 15 \\
10.0 \pm 2.4\end{array}$ & $\begin{array}{l}(17.0) \\
(24.0)\end{array}$ & $\begin{array}{l}31 \\
16\end{array}$ & $\begin{array}{r}86 \pm 19 \\
10.9 \pm 1.8\end{array}$ & $\begin{array}{l}(22.7) \\
(16.6)\end{array}$ & $\begin{array}{l}\text { NS } \\
\text { NS }\end{array}$ \\
\hline 20 & $\begin{array}{l}\text { a) } \\
\text { b) }\end{array}$ & $\begin{array}{l}38 \\
23\end{array}$ & $\begin{array}{c}167 \pm 24 \\
27.2 \pm 3.6\end{array}$ & $\begin{array}{l}(14.6) \\
(13.4)\end{array}$ & $\begin{array}{l}29 \\
14\end{array}$ & $\begin{array}{c}197 \pm 33 \\
34.5 \pm 4.2\end{array}$ & $\begin{array}{l}(16.9) \\
(12.3)\end{array}$ & $\begin{array}{l}S \\
S\end{array}$ \\
\hline 30 & $\begin{array}{l}\text { a) } \\
\text { b) }\end{array}$ & $\begin{array}{l}41 \\
23\end{array}$ & $\begin{array}{c}187 \pm 35 \\
34.4 \pm 3.4\end{array}$ & $\begin{array}{l}(18.5) \\
(10.0)\end{array}$ & $\begin{array}{l}34 \\
14\end{array}$ & $\begin{array}{c}196 \pm 28 \\
38.1 \pm 3.6\end{array}$ & $\begin{array}{r}(14.4) \\
(9.4)\end{array}$ & $\begin{array}{l}\text { NS } \\
\text { NS }\end{array}$ \\
\hline 60 & $\begin{array}{l}\text { a) } \\
\text { b) }\end{array}$ & $\begin{array}{l}39 \\
20\end{array}$ & $\begin{array}{c}222 \pm 45 \\
43.1 \pm 7.3\end{array}$ & $\begin{array}{l}(20.1) \\
(17.0)\end{array}$ & $\begin{array}{l}28 \\
13\end{array}$ & $\begin{array}{c}229 \pm 48 \\
48.3 \pm 9.0\end{array}$ & $\begin{array}{l}(21.0) \\
(18.6)\end{array}$ & $\begin{array}{l}\text { NS } \\
\text { NS }\end{array}$ \\
\hline 90 & a) & 19 & $217 \pm 36$ & $(16.7)$ & 15 & $228 \pm 46$ & $(20.0)$ & NS \\
\hline 120 & a) & 16 & $230 \pm 42$ & $(18.1)$ & 15 & $227 \pm 50$ & $(22.0)$ & NS \\
\hline \multicolumn{9}{|c|}{ Heart } \\
\hline 1 & $\begin{array}{l}\text { a) } \\
\text { b) }\end{array}$ & $\begin{array}{l}35 \\
24\end{array}$ & $\begin{array}{c}16 \pm 5 \\
1.4 \pm 0.5\end{array}$ & $\begin{array}{l}(30.5) \\
(39.3)\end{array}$ & $\begin{array}{l}29 \\
18\end{array}$ & $\begin{array}{c}18 \pm 6 \\
0.8 \pm 0.4\end{array}$ & $\begin{array}{l}(37.7) \\
(51.2)\end{array}$ & $\begin{array}{l}\text { NS } \\
\text { NS }\end{array}$ \\
\hline 10 & $\begin{array}{l}\text { a) } \\
\text { b) }\end{array}$ & $\begin{array}{l}45 \\
27\end{array}$ & $\begin{array}{c}36 \pm 7 \\
4.6 \pm 1.5\end{array}$ & $\begin{array}{l}(19.2) \\
(33.2)\end{array}$ & $\begin{array}{l}31 \\
16\end{array}$ & $\begin{array}{c}39 \pm 8 \\
4.1 \pm 1.2\end{array}$ & $\begin{array}{r}(21.2) \\
(7.4)\end{array}$ & $\begin{array}{l}\text { NS } \\
\text { NS }\end{array}$ \\
\hline 20 & $\begin{array}{l}\text { a) } \\
\text { b) }\end{array}$ & $\begin{array}{l}38 \\
23\end{array}$ & $\begin{array}{c}78 \pm 12 \\
12.2 \pm 1.6\end{array}$ & $\begin{array}{l}(15.8) \\
(13.6)\end{array}$ & $\begin{array}{l}29 \\
14\end{array}$ & $\begin{array}{r}82 \pm 12 \\
12.8 \pm 1.9\end{array}$ & $\begin{array}{l}(14.8) \\
(15.1)\end{array}$ & $\begin{array}{l}\text { NS } \\
\text { NS }\end{array}$ \\
\hline 30 & $\begin{array}{l}\text { a) } \\
\text { b) }\end{array}$ & $\begin{array}{c}40 \\
22\end{array}$ & $\begin{array}{r}91 \pm 12 \\
15.3 \pm 1.4\end{array}$ & $\begin{array}{c}(13.1) \\
(9.4)\end{array}$ & $\begin{array}{l}34 \\
14\end{array}$ & $\begin{array}{r}104 \pm 21 \\
13.9 \pm 2.2\end{array}$ & $\begin{array}{l}(20.0) \\
(15.5)\end{array}$ & $\begin{array}{r}\mathrm{S} \\
\mathrm{NS}\end{array}$ \\
\hline 60 & $\begin{array}{l}\text { a) } \\
\text { b) }\end{array}$ & $\begin{array}{l}39 \\
20\end{array}$ & $\begin{array}{c}108 \pm 16 \\
18.0 \pm 3.9\end{array}$ & $\begin{array}{l}(14.6) \\
(22.0)\end{array}$ & $\begin{array}{l}28 \\
13\end{array}$ & $\begin{array}{c}116 \pm 23 \\
18.7 \pm 2.4\end{array}$ & $\begin{array}{l}(19.5) \\
(13.1)\end{array}$ & $\begin{array}{l}\text { NS } \\
\text { NS }\end{array}$ \\
\hline 90 & a) & 19 & $106 \pm 15$ & $(14.0)$ & 15 & $115 \pm 22$ & $(18.7)$ & NS \\
\hline 120 & a) & 16 & $119 \pm 15$ & $(13.1)$ & 15 & $118 \pm 19$ & $(15.9)$ & NS \\
\hline
\end{tabular}

It was only the dry mass of the liver which increased more rapidly in voles of the autumn generation than in those of the spring generation, at the age of 10 to 30 days, and the dry mass of the kidneys in day-old voles was greater in animals from the spring than those of the autumn generation. 


\subsection{Occurrence of Trace Elements in Organs}

The INAA method used permitted of simultaneous identification in the vole organs in five age groups of 10 trace elements, of which 6 (iron, zinc, cobalt, selenium, antimony and europium) occurred in each sample, while 4 (chromium, mercury, scandium and cerium) could be identified and amounts defined only in certain of the samples (Table 3). The con-

Table 3

Concentration of trace elements $(\mathrm{ppm})$ in organs of voles of different generations during postnatal development. S, spring generation; A, autumn generation.

\begin{tabular}{|c|c|c|c|c|c|c|c|c|c|c|}
\hline \multirow{2}{*}{$\begin{array}{l}\text { Age, } \\
\text { days }\end{array}$} & \multicolumn{6}{|c|}{ Always present } & \multicolumn{4}{|c|}{ Occasionally present } \\
\hline & $\mathrm{Fe}$ & $\mathrm{Zn}$ & Co & $\mathrm{Se}$ & $\mathrm{Sb}$ & $\mathrm{Eu}$ & $\mathrm{Cr}$ & $\mathrm{Hg}$ & $\mathrm{Sc}$ & $\mathrm{Ce}$ \\
\hline \multicolumn{11}{|c|}{ Liver } \\
\hline $1 \mathrm{~S}$ & 613.1 & 602.8 & $0.01 *$ & 1.90 & 0.01 & 0.32 & - & - & - & 0.09 \\
\hline A & 2016.3 & 306.7 & 0.21 & 11.35 & 0.09 & 0.42 & - & - & - & 0.93 \\
\hline $10 \mathrm{~S}$ & 614.6 & 467.4 & $0.01 *$ & 0.65 & 0.02 & 0.15 & - & - & - & - \\
\hline A & 6889.9 & 646.4 & 0.14 & 3.96 & 0.16 & 0.20 & - & - & - & - \\
\hline $20 \mathrm{~S}$ & 421.5 & 1105.1 & 0.01 & $0.10^{*}$ & $0.002 *$ & 6.27 & - & - & - & 0.06 \\
\hline A & 3934.6 & 562.9 & 0.04 & 3.32 & 0.05 & $0.002^{*}$ & - & - & 一 & - \\
\hline $30 \mathrm{~S}$ & 1760.8 & 851.6 & $0.01 *$ & 0.94 & 0.04 & 0.04 & - & - & - & - \\
\hline A & 4335.8 & 586.1 & 0.03 & 3.55 & 0.05 & $0.002^{*}$ & - & - & - & - \\
\hline $60 \mathrm{~S}$ & 2153.4 & 767.8 & $0.01 *$ & 1.15 & 0.01 & 0.01 & - & - & - & - \\
\hline A & 6811.9 & 696.5 & 0.04 & 4.74 & 0.10 & $0.002 *$ & - & - & - & - \\
\hline
\end{tabular}

Kidneys

$\begin{array}{rrrrllllllll}1 & \mathrm{~S} & 56.4 & 1288.2 & 0.09^{*} & 5.14 & 0.03 & 0.99 & 12.98 & 0.17 & 0.015 & 0.06 \\ \mathrm{~A} & 805.8 & 1089.1 & 0.07 & 7.91 & 0.12 & 0.002^{*} & 5.37 & - & 0.019 & - \\ 10 \mathrm{~S} & 95.0 & 622.3 & 0.02^{*} & 2.19 & 0.05 & 0.21 & 6.63 & - & - & - \\ & \mathrm{A} & 825.5 & 998.6 & 0.10 & 5.61 & 0.53 & 0.002 * & 5.24 & - & 0.008 & - \\ 20 \mathrm{~S} & 107.8 & 598.7 & 0.01 * & 0.10 * & 0.05 & 0.08 & - & - & - & - \\ & \mathrm{A} & 1553.4 & 647.4 & 0.14 & 7.51 & 0.12 & 0.002^{*} & 5.17 & - & 0.009 & - \\ 30 & \mathrm{~S} & 320.7 & 600.9 & 0.01 * & 0.04^{*} & 0.07 & 0.03 & - & - & - & - \\ \mathrm{A} & 1661.6 & 610.5 & 0.10 & 7.98 & 0.12 & 0.002^{*} & - & - & - & - \\ 60 & \mathrm{~S} & 557.4 & 647.4 & 0.01 * & 1.33 & 0.06 & 0.03 & - & - & - & - \\ \mathrm{A} & 1624.4 & 547.5 & 0.08 & 8.02 & 0.21 & 0.002 * & - & - & - & -\end{array}$

Heart

\begin{tabular}{rrrllllllll}
$1 \mathrm{~S}$ & 486.5 & 687.2 & $0.14^{*}$ & 7.56 & 0.12 & 11.46 & - & - & - & 0.55 \\
$\mathrm{~A}$ & 2106.9 & 791.6 & 0.10 & 8.62 & 0.24 & $0.002^{*}$ & - & - & 0.029 & 0.11 \\
$10 \mathrm{~S}$ & 63.9 & 513.3 & $0.04^{*}$ & 1.42 & $0.01 *$ & 0.26 & - & - & - & 0.12 \\
$\mathrm{~A}$ & 1401.7 & 512.5 & 0.03 & 6.57 & 0.34 & $0.002^{*}$ & - & - & 0.009 & 0.11 \\
$20 \mathrm{~S}$ & 107.0 & 391.4 & $0.02 *$ & 0.86 & 0.09 & 0.02 & - & - & - & - \\
$\mathrm{A}$ & 2046.8 & 543.9 & 0.03 & 4.38 & 0.17 & $0.002 *$ & 1.78 & - & 0.009 & - \\
$30 \mathrm{~S}$ & 460.4 & 312.0 & $0.02 *$ & 1.17 & 0.34 & 0.38 & - & - & - & - \\
$\mathrm{A}$ & 2112.7 & 630.5 & 0.03 & 3.49 & 0.15 & $0.002 *$ & - & - & 0.009 & - \\
$60 \mathrm{~S}$ & 450.5 & 580.1 & $0.01 *$ & 1.11 & 0.08 & 0.02 & - & - & - & - \\
$\mathrm{A}$ & 1796.2 & 653.1 & 0.07 & 4.55 & 0.13 & $0.002 *$ & - & - & 0.033 & - \\
\hline
\end{tabular}

* Concentration was less than shown in the table. 
$\therefore$ centrations of several of the elements in some of the samples were on the borderline of the sensitiveness of the method, so that they could be defined only semi-quantitatively, giving the threshold value.

\subsubsection{Concentration of Trace Elements}

Concentrations of elements regularly occurring in the vole organs were subject to certain variations during the voles' postnatal development. Elements varying only slightly included $\mathrm{Zn}$ and $\mathrm{Co}_{\mathrm{n}}$ (differences 4-20 times), medium degree of variability - Fe, Se and $\mathrm{Sb}$ (differences 120-280-times) and considerable variability - Eu (differences over 5700-times).

The only element whose concentration increased in the organs of voles of both generations during postnatal development was Fe. Voles of the spring generation differed distinctly from those of the autumn generation in respect of $\mathrm{Fe}$ concentration in their organs. As early as in day-old voles of the autumn generation there was 3-4 times greater concentration of $\mathrm{Fe}$ in the liver and heart, and 14 times greater in kidneys, as compared with voles of the spring generation. This difference was maintained in the liver and heart, but in the kidneys decreased to the level of differences in the other tissues up to the 60th day of life.

Concentrations of $\mathrm{Zn}$ in the different organs were most similar to each other when compared with other elements. The greatest variations in $\mathrm{Zn}$ concentration were found in vole kidneys. Differences between generations were smaller than in the case of Fe. Day-old voles of the spring generation had far higher $\mathrm{Zn}$ concentrations (about twice higher) than voles of the autumn generation in the liver only. During postnatal development $\mathrm{Zn}$ concentration noticeably decreased in the kidneys and heart of the voles up to the 30 th day of their lives, after which there was no variation.

Concentration of Co could be defined only semi-quantitatively in all the organs of spring generation voles. The course taken by variations in this parameter during postnatal development was similar in the liver and heart, but differed from the other organs in the kidneys. A particularly great difference between voles of the two generations in respect of Co concentration was found in the liver of day-old voles (about 20 times as much).

The most distinct differences between voles of different generations in all age groups occurred in respect of. Se concentration. The organs of autumn generation voles contained a higher Se concentration than in those of the spring generation.

$\mathrm{Sb}$ concentration in vole organs during their postnatal development 
varied irregularly. Abrupt increases and decreases in $\mathrm{Sb}$ concentration were recorded in organs of voles of different age, higher Sb concentrations occurring in the organs of autumn generation voles than in spring voles. Even day-old voles of the autumn generation contained $2-9$ times higher $\mathrm{Sb}$ concentration in their organs than spring generation voles.

$\mathrm{Eu}$ concentrations differed most from each other in organs of voles of different age. In autumn generation voles almost all samples contained

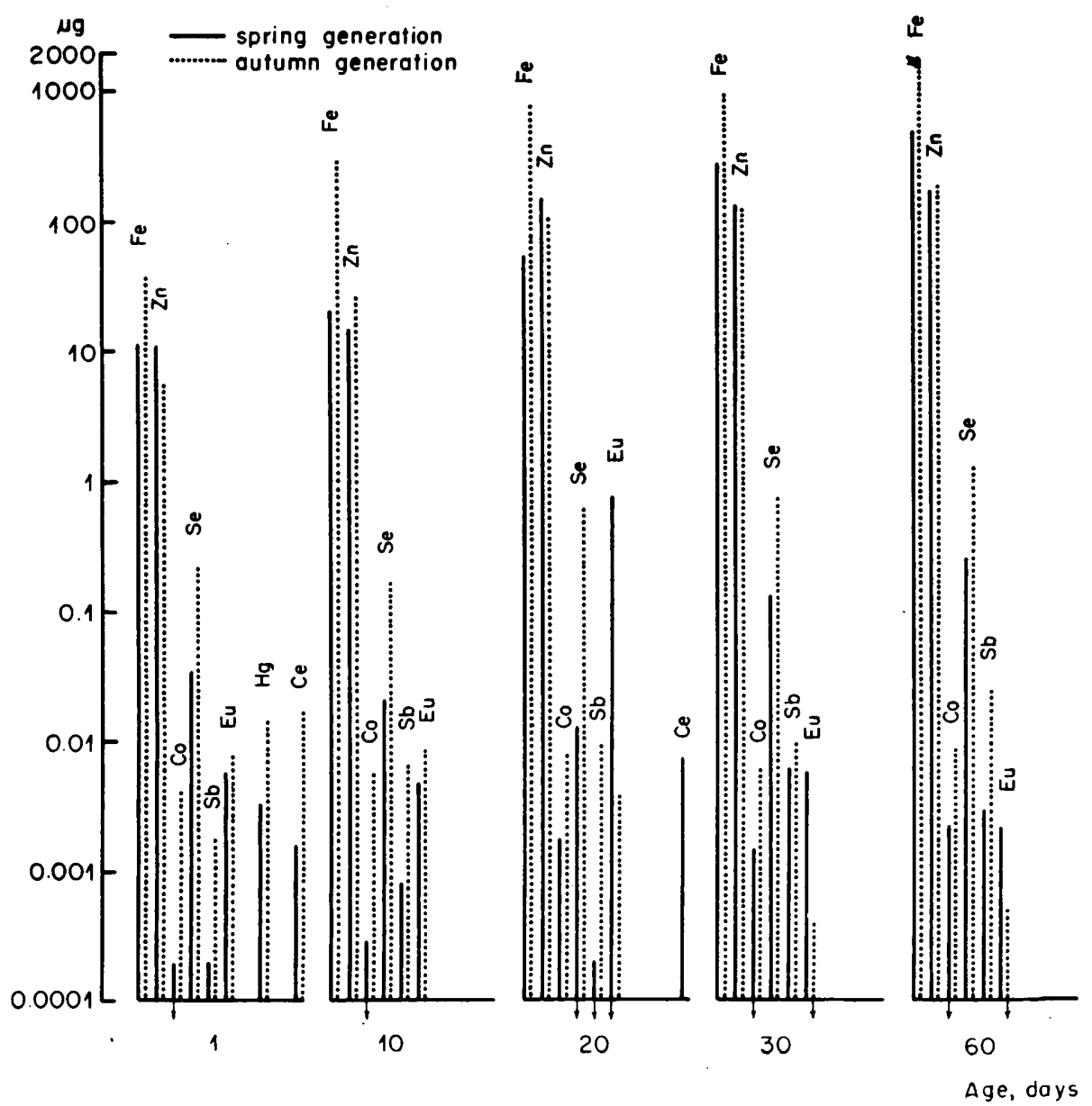

Fig. 1. Contents of trace elements in the liver of voles of different generations during postnatal development. Arrows indicate concentrations below the sensitive capacity.

Su concentrations below the sensitive capacity of the method and were defined semi-quantitatively. In spring generation voles Eu concentration decreased greatly in all the organs of voles from 1 to 10 days old. An 
exceptionally high Eu concentration was found in the liver of 20-day old voles of the spring generation.

Trace elements found sporadically in samples usually occurred in the vole organs from the 1 st to the 20 th day of the animals' lives. No $\mathrm{Cr}$ or Sc were found in the liver or $\mathrm{Hg}$ in the heart of voles of the two generations. Chromium was identified in the kidneys of voles from 1 to 20 clays old in similar concentrations, or concentrations decreasing with the animal' age. Mercury occured in the liver of day-old voles of the two generations and in the kidneys of 1- and 10-day old voles of the spring generation. Scandium was recorded in the kidneys of voles from

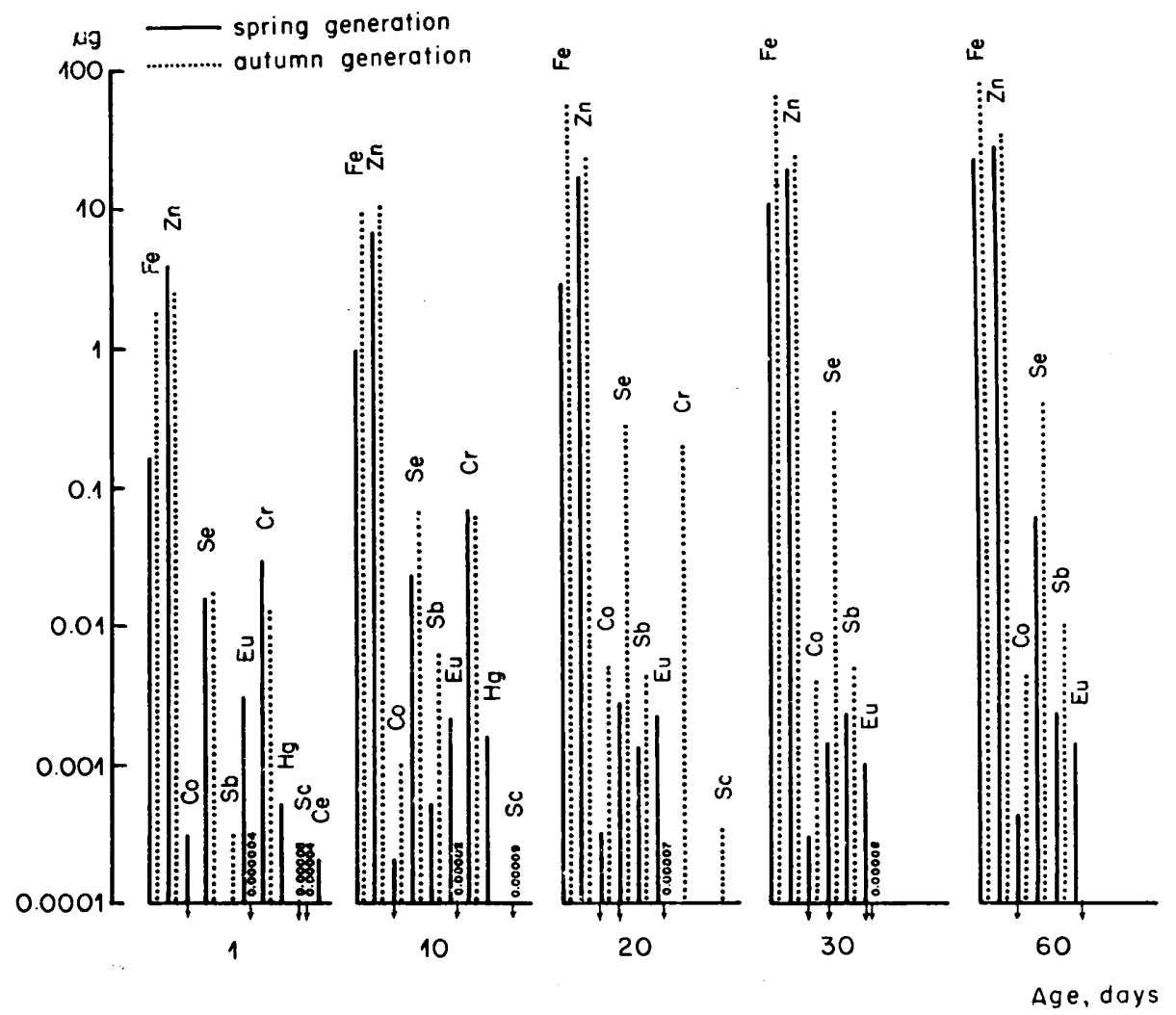

Fig. 2. Contents of trace elements in the kidneys of voles of different generations during postnatal development. Explanation see Fig. 1.

1 to 20 days old and in the heart of autumn generation voles in all age groups. Cerium occurred in the organs of voles of different generations from the 1 st to the 20 th day of the animals' lives.

Concentrations of the majority of the trace elements analyzed in organs of voles of the two generations were greatest on the 1st or 10th 
day of the animals' lives, after which there was a marked decrease in concentration up to the 20 th day of life. Variations in the concentration of elements in organs were greatest in voles of the two generations at the age of from 10 to 30 days of life. During the last period of development analyzed, i.e. between the. 30 th and 60th day of the voles' lives, concentration of most of the elements increased in the liver and kidneys, and decreased in the heart.

The mean concentrations of elements for the whole period of the voles' lives occurred in a sequence from the highest to the lowest in different organs, differently for voles of the generations compared. Thus in the organs of voles of the spring generation: $\mathrm{Co}, \mathrm{Se}$ and $\mathrm{Sb}-$ heart $>$ $>$ kidneys $>$ liver, Eu - heart $>$ liver and kidneys, $\mathrm{Zn}$ - liver $>$ kidneys $>$ $>$ heart; in organs of the autumn generation voles: $\mathrm{Zn}$, Se and $\mathrm{Sb}$ kidneys $>$ heart $>$ liver, Co - kidneys $>$ liver $>$ heart: Eu - liver $>$ heart $>$ $>$ kidneys; in organs of voles of both generations: Fe - liver $>$ heart $>$ $>$ kidneys. Mean concentrations of these elements in the liver and kidneys were about from 1.5 to 9 times higher in autumn generation voles than those of the spring generation. Only $\mathrm{Zn}$ in the liver and kidneys and $\mathrm{Eu}$ in all organs occurred in greater amounts in the spring generation than in autumn generation voles.

\subsubsection{Contents of Trace Elements}

In the completely dry mass of vole organs the contents of the majority of the elements usually increased together with increasing weight of the dry mass of organs during the postnatal development of these animals.

Continual increase was recorded for $\mathrm{Fe}, \mathrm{Zn}$ and $\mathrm{Co}$ contents in voles of both generations and for $\mathrm{Sb}$ - in voles of the autumn generation for livers during the course of the animals' development. Se contents in the liver of voles of both generations decreased from the 1st to the 20 th day of the animals' lives, after which it increased up to the 60th day. $\mathrm{Sl}$ contents in spring generation voles and $\mathrm{Eu}$ in voles for both generations, however, were subject to irregular variations, with a marked decrease in the contents of these elements in the liver of 30- and 60-day old voles. Elements in greater amounts in the liver of autumn generation voles than in the liver of the spring generation in each group were $\mathrm{Fe}$, $\mathrm{Co}_{\mathrm{O}} \mathrm{Se}$ and $\mathrm{Sb} . \mathrm{Zn}$ and $\mathrm{Eu}$ contents in the liver were higher in the majority of age groups of the spring generation voles than in the autumn generations voles. The liver of day-old voles of the autumn generation contained in their lives 3 times as much Fe, 19 times as much Co, 6 tirres as much Se, 8 times as much $\mathrm{Sb}, 4$ times as much $\mathrm{Hg}$ and 10 times as much $\mathrm{Ce}$, a similar amount of $\mathrm{Eu}$ and an amount of $\mathrm{Zn}$ twice smaller 
than for spring generation voles. Sixty-day old voles of the autumn generation contained 4 times more $\mathrm{Fe}, 5$ times more Co and Se, 8 times more $\mathrm{Sb}$, the same amount of $\mathrm{Zn}$ and 4 times less $\mathrm{Eu}$ than spring generation voles.

Continual increase in $\mathrm{Fe}$ and $\mathrm{Zn}$ contents in kidneys was found in voles of the two generations, and of $\mathrm{Se}$ in the autumn generation, and $\mathrm{Sb}$ in voles of the spring generation. Co and $\mathrm{Sb}$ contents in the kidneys of autumn generation voles and $\mathrm{Se}$ in the kidneys of spring generation voles are subject to irregular variation, during which the common ten-

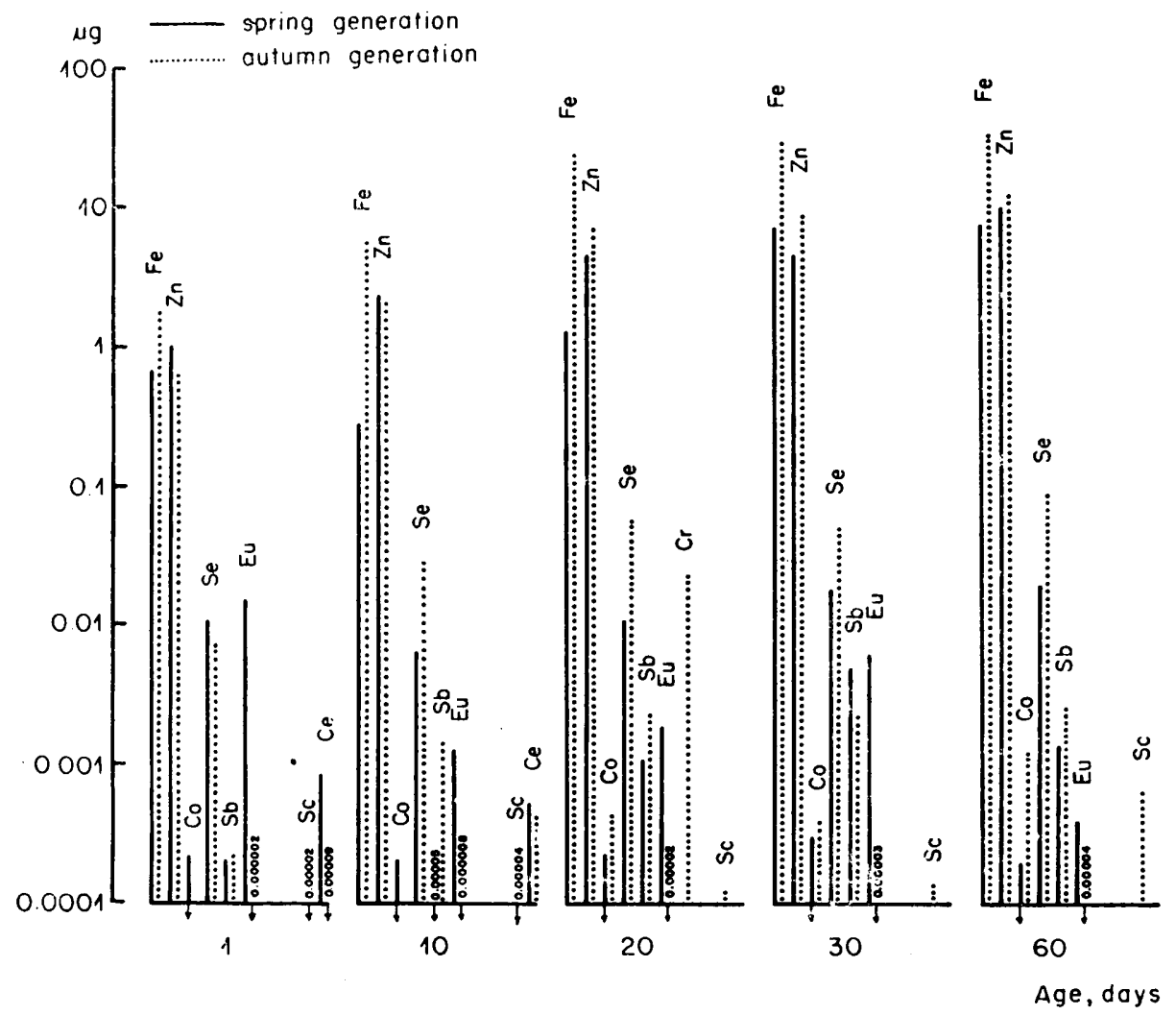

Fig. 3. Contents of trace elements in the heart of voles of different generations during postnatal development. Explanation see Fig. 1.

dency is to increase in the first two or three age groups. Contents of $\mathrm{Fe}, \mathrm{Co}$, Se and $\mathrm{Sb}$ were greater in the kidneys of autumn generation voles than the spring generation in each age group. $\mathrm{Zn}$ contents were higher only in kidneys of day-old voles of the spring than of the autumn generation, while in the other age groups $\mathrm{Zn}$ contents predominated in the kidneys of the autumn generation voles. Contents of one element - 
$\mathrm{Eu}$ - were higher in the kidneys of the spring than of the autumn generation voles of the whole period of development. In day-old voles differences in contents of elements were smaller between voles of the generations compared than in the case of the liver. Adult 60-day old voles of the autumn generation contained 3 times more Fe, 10 times more $\mathrm{Co}, 7$ times more Se and 4 times more $\mathrm{Sb}$, the same amount of $\mathrm{Zn}$ and about 13 times less $\mathrm{Eu}$ in the kidneys than voles of the spring generation.

A continual increase in $\mathrm{Fe}, \mathrm{Zn}, \mathrm{Co}$, Se and $\mathrm{Sb}$ contents was found in the hearts of voles (Fig. 3) in the autumn generation. In the hearts of spring generation voles $\mathrm{Fe}, \mathrm{Se}, \mathrm{Sb}$ and $\mathrm{Eu}$ contents decreased between the lst and 10th day of the animals' lives, increased from the 10th to the 30 th day, after which they became stabilized or decreased between

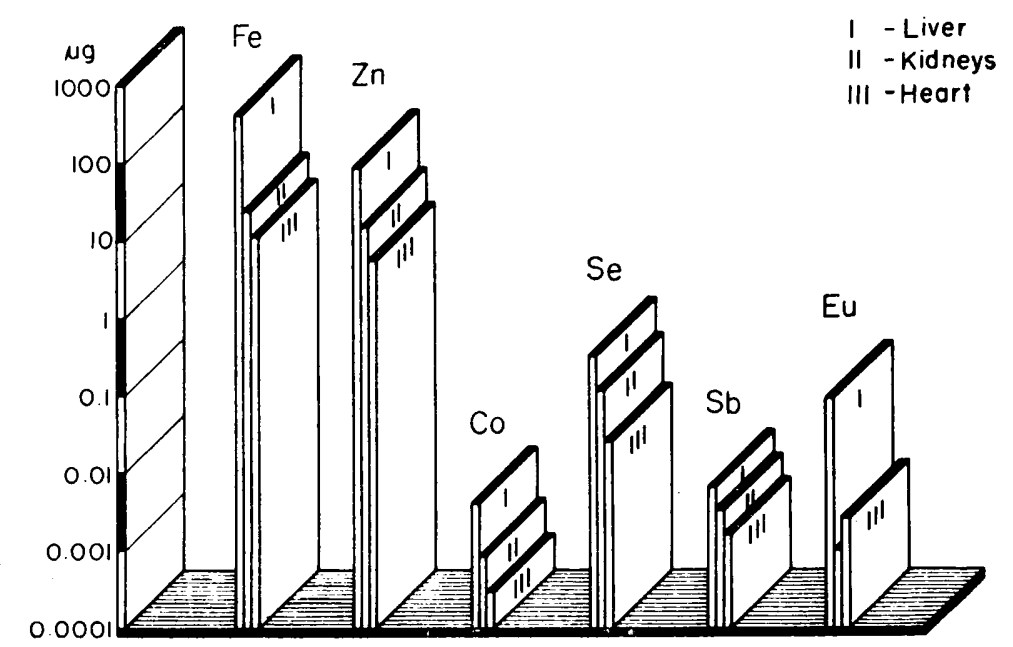

Fig. 4. Mean contents of trace elements in the organs of all voles examined.

the 30 th and 60 th day of life. In this generation only $\mathrm{Zn}$ contents in the heart continually increased with increasing age of the animals. In day-old voles the contents of the majority of elements in the heart are only slightly higher in autumn than in spring generation voles (with the exception of $\mathrm{Eu}$ ). In 60 -day old voles of the autumn generation the kidneys contain 4 times more $\mathrm{Fe}$ and $\mathrm{Se}$, twice more $\mathrm{Sb}, 6$ times more $\mathrm{Co}$, similar amounts of $\mathrm{Zn}$ and 10 times less $\mathrm{Eu}$ than in voles of the spring generation.

When differences between contents of elements in the organs of voles of the generations compared are considered it can be seen that decidedly higher $\mathrm{Fe}, \mathrm{Co}$ and $\mathrm{Sb}$ contents occurred in newborn voles, and lower contents of $\mathrm{Eu}$ and $\mathrm{Zn}$ in voles of the autumn than of the spring gene- 
ration. The greatest differences in contents of elements occurred in the liver of day-old voles of the generations compared. Adult voles are characterized by distinctly higher $\mathrm{Fe}, \mathrm{Co}$, $\mathrm{Se}$ and $\mathrm{Sb}$ contents, similar $\mathrm{Zn}$ contents and markedly lower Eu contents in all organs of voles of the autumn generation than of the spring generation. Mean contents of constantly occurring elements calculated for all voles, without division into age groups and generations, were highest in the liver, lower in the kidneys and lowest in the heart, with the exception of $\mathrm{Eu}$, the contents of which were lowest in kidneys (Fig. 4).

\subsection{Oxidation-reduction Activity of the Organs}

The oxidation-reduction activity of different vole organs decreased to a different degree with increasing age of the animals (Table 4). The level and degree of decrease in this activity was characteristic of the organ and depended on the season in which the voles were born. Each organ of the voles during their postnatal development had three levels of activity.

\section{Table 4}

Oxidation-reduction activity (thousand impulses) of organs of voles of different generations during postnatal development.

\begin{tabular}{rcccccc}
\hline $\begin{array}{c}\text { Age, } \\
\text { days }\end{array}$ & $\mathrm{N}$ & $\begin{array}{c}\text { Spring generation } \\
\overline{\mathrm{x}} \pm \text { S.D. }\end{array}$ & $(\mathrm{CV})$ & $\mathrm{N}$ & $\begin{array}{c}\text { Autumn generation } \\
\overline{\mathbf{x}} \pm \mathrm{S} . \mathrm{D} .\end{array}$ & $(\mathrm{CV})$ \\
\hline & & & Liver & & \\
1 & 20 & $4953 \pm 987$ & $(19.9)$ & 13 & $4208 \pm 418$ & $(9.9)$ \\
10 & 18 & $3861 \pm 441$ & $(11.4)$ & 15 & $3758 \pm 729$ & $(19.4)$ \\
20 & 15 & $1031 \pm 201$ & $(19.5)$ & 15 & $938 \pm 183$ & $(19.5)$ \\
30 & 18 & $724 \pm 106$ & $(14.6)$ & 20 & $534 \pm 113$ & $(21.1)$ \\
60 & 19 & $387 \pm 72$ & $(18.6)$ & 15 & $432 \pm 77$ & $(17.8)$ \\
90 & 19 & $288 \pm 48$ & $(16.7)$ & 15 & $357 \pm 60$ & $(16.8)$ \\
120 & 16 & $214 \pm 27$ & $(12.5)$ & 15 & $326 \pm 62$ & $(18.9)$ \\
& & & Kidneys & & & \\
1 & 18 & $9977 \pm 1960$ & $(19.6)$ & 13 & $8584 \pm 1347$ & $(15.7)$ \\
10 & 18 & $2692 \pm 540$ & $(20.0)$ & 15 & $2101 \pm 411$ & $(19.6)$ \\
20 & 15 & $694 \pm 163$ & $(23.5)$ & 15 & $564 \pm 57$ & $(10.1)$ \\
30 & 18 & $514 \pm 89$ & $(17.4)$ & 20 & $456 \pm 93$ & $(20.4)$ \\
60 & 19 & $484 \pm 77$ & $(15.8)$ & 15 & $497 \pm 83$ & $(16.6)$ \\
90 & 19 & $319 \pm 47$ & $(14.8)$ & 15 & $493 \pm 85$ & $(17.2)$ \\
120 & 16 & $259 \pm 36$ & $(13.9)$ & 15 & $413 \pm 51$ & $(12.2)$ \\
& & & Heart & & & \\
1 & 11 & $17050 \pm 3329$ & $(19.5)$ & 11 & $13407 \pm 1742$ & $(13.0)$ \\
10 & 18 & $17876 \pm 1503$ & $(8.4)$ & 15 & $16823 \pm 2973$ & $(17.7)$ \\
20 & 15 & $15071 \pm 2330$ & $(15.5)$ & 15 & $13601 \pm 1769$ & $(13.0)$ \\
30 & 18 & $12976 \pm 1765$ & $(13.6)$ & 20 & $12921 \pm 1500$ & $(11.6)$ \\
60 & 19 & $10909 \pm 2093$ & $(19.2)$ & 15 & $12698 \pm 2138$ & $(16.8)$ \\
90 & 19 & $10015 \pm 1364$ & $(1.3 .6)$ & 15 & $12221 \pm 1307$ & $(10.6)$ \\
120 & 16 & $8997 \pm 987$ & $(11.0)$ & 15 & $11737 \pm 1951$ & $(16.6)$ \\
\hline
\end{tabular}


Day-old voles exhibited maximum activity in the liver (CHL 14-16 times greater in comparison with $C H L$ of the model reaction). This high level of activity is maintained, with only a slight decrease, up to the 10 th day of the voles' lives. A medium level of activity was characteristic of the liver of 20 - and 30-day old voles ( $C H L 3$ times greater). 'The activity of the liver in voles from 60 to 120 days old remained on a low level ( $C H L$ about 1.5 times greater). The average level of activity of the liver was $15-20 \%$, and low level only $6-10 \%$ of the oxidationreduction activity of the liver on a high level.

Oxidation-reduction activity of the kidneys of day-old voles was higher than the activity of the liver in voles of the same age, and only then was on a high level (CHL 28-32 times greater in comparison with the $C H L$ of the model reaction). By the 10 th day the activity of kidneys had reached the average level ( $\mathrm{CHL} 7-8$ times greater), while the activity of kidneys in voles from 20 to 60 days old was on a low level (CHL 1.6-2 times greater). In voles from 90 to 120 days old the activity of the kidneys decreased further (spring generation) or failed to change (autumn generation). The average level of oxidation-reduction activity in the kidneys was $24 \%$ and low-level $5-6 \%$ of the activity of kidneys on a high level.

The oxidation-reduction activity of the heart in voles was greatest in all age groups in comparison with the other organs, and was characterized by the least variations during the postnatal development of the voles. A high level of activity of the heart was found in voles on the 10th day of life (CHL 56-59 times greater than the CHL of the model reaction). Day-old and 20-day old voles, however, had an average level of activity of the heart ( $\mathrm{CHL} 45-55$ times greater). The activity of the heart in voles over 20 days old was on a low level (CHL 30-40 times greater), and this level continued to decrease in voles of the spring generation up to the 120 th day of the animals' lives. Mean level of oxidation-reduction activity of the heart in voles forms $80-88 \%$, and low level $-50-70^{0} \%$, of the activity of the heart on a high level.

Although in all the organs examined during the course of postnatal development oxidation-reduction activity was on a high level in the younger voles, and at a later age, on a medium and low level, each of the organs had a different, characteristic course of variations during the voles' development. The establishment of activity of the organs on a defined low level, lowest in the liver and highest in the heart, occurred at different ages of these animals. Kidneys attained this level earliest, on the 20th day of life of the voles, and the liver latest, on the 60th day of life, similarly in voles of the two generations. The heart, however, reached a low level as from the 30th day of life, but only in voles of 
the autumn generation. In voles of the spring generation there was no stabilization of the activity of the heart on a low level. Reduction in the level of activity of organs from a high to medium level was lesser in voles of the spring than of the autumn generation. Reduction of the activity of all organs from a high to a low level was lesser in voles of the autumn than of the spring generation. Activity of the organs became stabilized on a lower level in voles of the spring than of the autumn generation.

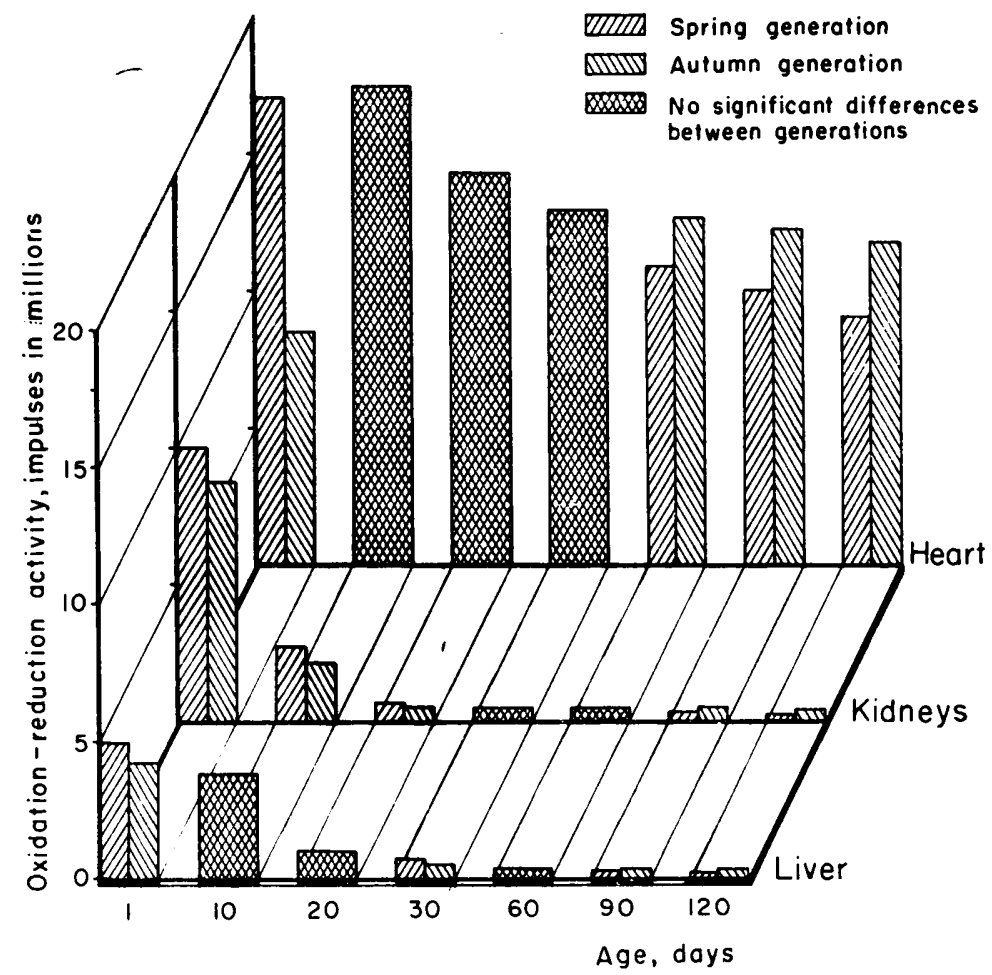

Fig. 5. Variations in oxidation-reduction activity of the organs of voles of different generations during postnatal development.

The course taken by changes in the activity of vole organs during postnatal development was similar in voles of both generations, but a different degree of activity of the organs was found in different periods of development, depending on the season during which the animals had been born (Fig. 5). In day old voles all organs differed to a statistically significant degree - greater activity was characteristic of voles of the spring generation as compared with those of the autumn generation. Such differentiation was maintained in the various organs 
through different periods of the voles' lives, then became balanced, after which, as from the 60th day, the activity of the heart, and from the 90th day of the voles' life also the activity of the remaining organs, was statistically significantly higher in autumn than in spring voles.

\subsubsection{Correlation between Weight and Activity of the Organs}

During comparison of variations in the absolute weight of organs and their oxidation-reduction activity, a statistically significant $(P>.001)$ ne-

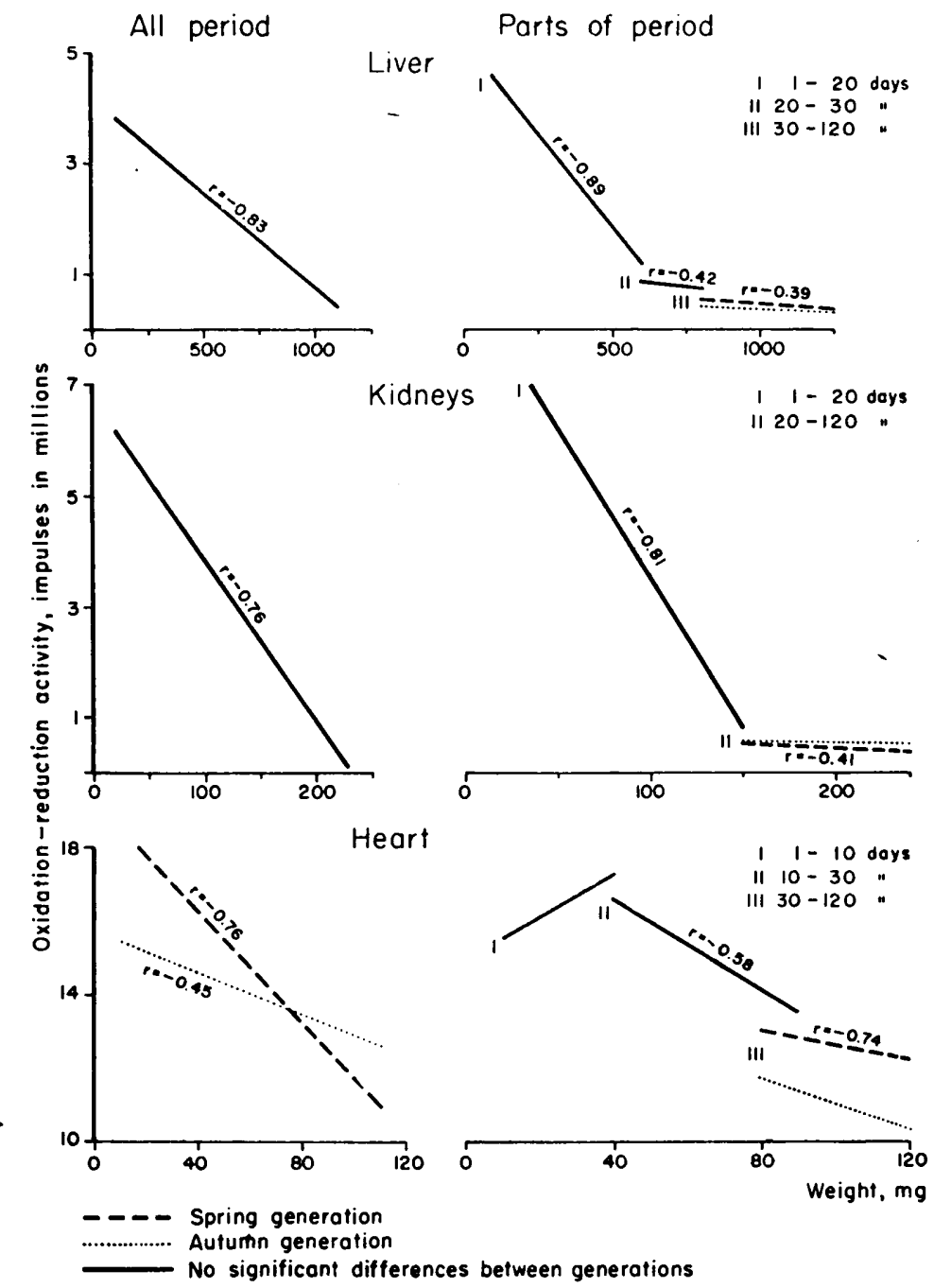

5ig. 6. Correlation between oxidation-reduction activity and weight of organs of voles of different generations during postnatal development. 
gative correlation was found between these two indexes in voles of both generations for the whole study period of postnatal development (Fig. 6). Coefficients of correlation in the liver and kidneys of voles of the two generations were not found to differ when compared, but differences occurred in respect of the heart: the coefficient of correlation in the heart of spring voles was higher than in the autumn generation voles. Taking into account the activity levels of organs the whole study period of the voles' postnatal development was divided into part-periods in which a different correlation of these two indexes occurred in the organs. The highest during the study period was the negative correlation between weight and activity of the liver and kidneys in voles from 1 to 20 days old, and of the heart in voles from 10 to 30 days old, in both generations. No significant correlation was found between weight and activity of organs in voles of the autumn generation from 30 to 120 days old (liver and heart), or even from the 20th day of their lives (kidneys). In voles of the spring generation during the same period of development there was a negative correlation between weight and oxidation-reduction activity of all the organs examined.

\subsubsection{Inactivation of Organ Homogenates}

In order to obtain a greater amount of information as to the participation of elements in oxidation-reduction activity, chemical and thermal inactivation was applied to enzymes contained in homogenates of vole organs (Table 5). Voles were chosen for the experiments for the

Table 5

Chemical and thermal inactivation of oxidation-reduction activity (thousand impulses) of organs of 20-day old voles.

\begin{tabular}{|c|c|c|c|c|c|c|}
\hline \multirow{2}{*}{ Inactivation } & \multicolumn{2}{|c|}{ Liver } & \multicolumn{2}{|c|}{ Kidneys } & \multicolumn{2}{|l|}{ Heart } \\
\hline & Activity & $\%$ & Activity & $\%$ & Activity & $\%$ \\
\hline Control & 654 & 100 & 345 & 100 & 17392 & 100 \\
\hline Control+ $\mathrm{KCN}_{1} \cdot 10^{-3} \mathrm{M}$ & 15885 & 2430 & 13784 & 4117 & 40013 & 230 \\
\hline Control+KCN $1 \cdot 10^{-4} \mathrm{M}$ & 3980 & 595 & 2794 & 834 & 37132 & 254 \\
\hline Control & 836 & 100 & 387 & 100 & 14593 & 100 \\
\hline Control $+\mathrm{NaN}_{8} 1 \cdot 10^{-3} \mathrm{M}$ & 7838 & 937 & 3706 & 981 & 33734 & 231 \\
\hline Control $+\mathrm{NaN}_{3} 1 \cdot 10^{-4} \mathrm{M}$ & 33333 & 3985 & 23621 & 6252 & 44188 & 303 \\
\hline Control & 654 & 100 & 335 & 100 & 15497 & 100 \\
\hline Thermic inactivation & 51584 & 7891 & 42514 & 12698 & 34433 & 222 \\
\hline
\end{tabular}

organs of which a medium level of oxidation-reduction activity had been found (20 days old). The addition of substances blocking oxidation-reduction enzymes $\mathrm{KCN}$ and $\mathrm{NaN}_{3}$, in each case altered the course of the catalyzed reaction and the activity values of organs in relation to the 
control reaction, which was the reaction with the intact homogenate Both chemical substances inactivating oxidation-reduction enzymes exhibited maximum action on homogenates of kidneys, and least or. heart homogenates. KCN increased the activity of the liver and kidneys to a greater degree at a concentration of $1 \times 10^{-3} \mathrm{M}$, and $\mathrm{NaN}_{3}$ at a concentration of $1 \times 10^{-4} \mathrm{M}$. The effect of the two chemical substances on heart activity was similar, irrespective of their concentration.

Chemical inactivation, like thermal inactivation, does not cause reduction in photon emission of chemiluminescence reaction, but changes and prolongs in time the course of the reaction, which leads to an increase in the oxidation-reduction activity value of the homogenates. Chemical inactivation increases the activity of the liver by 6 to 40 times as much, and thermal inactivation by 80 times as much, that is, twice greater than chemical inactivation. Inactivation acts similarly, but to a greater degree, on kidney homogenates. Chemical inactivation increases the activity of kidneys by 8 to 62 times as much, and thermal inactivation by 127 times as much. The oxidation-reduction activity of the heart is similar after chemical and thermal inactivation in each case, being increased by approximately twice as much in relation to the control reaction.

\section{DISCUSSION}

\subsection{Measurement Method}

The method chosen for examining trace element contents in vole organs made it possible to identify 10 elements very exactly, including those elements which are rarely included in studies, on account of their extremely small amounts in biological material. The close similarity of identification of some elements by the methods of atomic absorption spectroscopy and INAA (Turkstra et al., 1977) justifies the assumption that the results obtained by different research workers will be comparable, despite the use of different methods. Considerable discrepancies have, however, been found so far in literature, arising from differences in the study biological material and probably also from difference in methods. On this account the results obtained in this paper should be treated as comparative only. The material collected cannot supply an answer as to whether the values obtained for concentrations of elements in vole organs are characteristic of the whole species, or only of its local populations. The fact, however, that the studies were carried out on animals obtained from one of the areas least polluted by man in Poland justifies the concentrations of elements obtained being treated as a zcro 
index for this species of mammal, which may act as a reliable indicator of environment changes.

Variations in individual contents of elements in the vole organs have not been estimated in this paper, but the concentrations determined, although forming mean values for over ten individuals of uniform age, differ to so great a degree, depending on the age of the voles and the season of their birth, that they may be considered to give a clear picture of changes in the contents of trace elements in the organs of voles during their postnatal development. Oxidation-reduction activity was measured separately for each individual. The coefficients of variation of this index are similar to each other (S. D. $=10-20$ ).

Results of blocking oxidation-reduction enzymes in tissue homogenates and thermal inactivation of the homogenates' activity drew attention to the participation of inorganic substances in maintenance of a given level of oxidation-reduction activity in vole organs. The similarity of variations in the activty of the organs and of the concentrations in them of trace elements during the first month of the voles' lives suggests that these two, apparently distant, indices are closely connected. This connection is different in different organs and applies to varying degrees to the elements examined, each of which performs a different role in the organism and is involved to a different degree in the oxidation-reduction processes taking place in the organs during the animals' postnatal development.

\subsection{Description of Postnatal Development}

There are few data in literature on variations in the concentration of different elements in animal organs during their development. The level of elements in organic fluids and tissues depends on a very great number of factors, among which is the animal's age. In the human organism $\mathrm{Cr}$ contents gradually decreases with age (Tipton \& Cook, 1961), while Co level remains unchanged. In addition the majority of elements may be subject to accumulation in parenchymatous organs (liver, kidneys).

Allowing for inequalities in the postnatal development of small mamirals (Pearson, 1962), maximum concentrations of elements in the organs is observed to occur during the first, slower growth phase of voles (1-10 days). In the subsequent phase of accelerated growth (10-30 days) maximum differentiation and variations in concentration of elements were found in the vole organs. The maximum concentrations of elements in vole organs after birth suggest that these elements must have accumulated during the prenatal period of the development of Acta Theriologica $\mathbf{- 8}$ 
young voles. The majority of the trace elements examined are known to move about in the organism and easily penetrate through the placenta to the embryo (see Underwood, 1962). The energy requirements of the gestating female increase by only $24 \%$, but voles are born fairly immature. During the lactation period, when the nursing females are found to have an almost double increase in food requirements (Kaczmarski, 1966), the weight of the young organs increases very rapidly, but concentrations of elements do not increase. When the concentrations of the majority of elements $(\mathrm{Fe}, \mathrm{Zn}, \mathrm{Co}, \mathrm{Se}, \mathrm{Eu}, \mathrm{Cr}$ ) in the organs of voles on the day of their birth are treated as a kind of pool accessible to the foetus during the prenatal period, it can be said that during the nest period this pool decreases to varying degrees. During the period of accelerated growth in which the weight of the dry mass of the organs increases most rapidly, but the energetic efficiency of tissues is from 3 to 5 times lower than during the period between the first and tenth day of life (Gębczyński, 1975), the concentration of elements in the organs, particularly in the kidneys, becomes greatly reduced. Even the contents of elements in the whole dry mass of the organs of some voles decrease during this period. Such variation can be clearly seen among the elements allocated to the group of sporadic elements, which were identified mainly in voles from 1 to 20 days old. After the 20th day, when the young voles begin to feed on natural food, the concentration of the majority of elements either increases or becomes stabilized.

Changes in body size of the voles are accompanied by rapid development of the physiological functions, which results in young voles, towards the end of the first month of life, having similar or identical physiological indices as those of adult individuals. General metabolic level is lowest in voles, as it is in many other species of small mammals, during the initial period of life, but the amount of energy deposited from assimilated energy is greatest at that time (up to $60^{\%} \%$ ) Gębczyński, 1975). Such high metabolic activity is reflected in the oxidation-reduction activity of the voles' organs, which decreases with age in a similar way to changes in deposited energy. In voles over 20 days old oxidation-reduction activity of the liver and kidneys forms only from $5-10 \%$ of the activity of organs in newborn voles, whereas the amount of deposited energy does not exceed $5 \%$ of assimilated energy.

One organ deserves particular attention - the heart, the oxidationreduction activity of which increases significantly after birth in all voles and reaches a maximum on the tenth day of life, after which it decreases in successive age groups of these animals. This type of variation is connected with the formation of thermoregulation mechanisms. The body temperature of the vole reaches the level proper to adult in- 
dividuals $\left(37-39^{\circ} \mathrm{C}\right)$ and becomes stabilized about the eighteenth day of the animals' life (Gębczyński, 1975). The very high activity of the heart of voles about the tenth day of life, that is, during the period when the voles must produce large amounts of heat, which is, however, lost more rapidly than in the case of older individuals, is understandable. The only small variations in the level of activity in comparison with other organs can also be observed during chemical and thermal inactivation of heart homogenates. This is the organ with maximum oxidationreduction activity, subject to slight variations only under the effect of different external factors.

The negative correlation between the weight of the organs and their oxidation-reduction activity in voles over a month old was observed to become less close. Attention was given to the course of variations in correlation connections between different morphological indices of organs in small mammals, on account of their part in the complicated process of the animals' growth and development (Jemielianov, 1976). In all early stages of development of the animal the correlation between different indexes is distinct and natural selection favours the survival of individuals with strongly marked correlation connections, but later these connections usually become less close. This is of particular importance in relation to all kinds of changes in living conditions which make it necessary for the organism to alter the metabolic level, e.g. during the period of sexual maturation. This reduction in correlation connections may precede physiological adjustment, which should take place within a short time and involves the animals in only small energy losses.

\subsection{Generation Differentiation}

In respect of concentration and contents of trace elements in the organs of voles of the generations compared it is possible to distinguish two types of elements. The first type includes $\mathrm{Fe}, \mathrm{Co}$, Se and Sb, more of which are contained in the organs of the autumn voles than in those of spring voles, in each age group. The second type includes Eu and, to a lesser degree, $\mathrm{Zn}$, more of which is present in the organs of spring voles than autumn voles.

A very considerable amount of information has been collected on the part played in the organism by type I elements - Fe, Co and Se. Their participation in a large number of enzymes such as hemo- and flavoproteins, cobalimin, selenoenzyme- gluthathione peroxidase, forms evidence of their active participation in oxidation-reduction processes. The 
role of $\mathrm{Fe}, \mathrm{Co}$ and $\mathrm{Se}$ in normal functioning of erythrocytes, and in action in cells for protection from the toxic products of oxidation activity, is well known. A greater part of these bio-elements in the organs may point to the greater capacity for adaptation of the organism in voles of the autumn generation to life under the more difficult habitat conditions than those in which voles of the spring generation live during development. The effect of Se combined with vitamin $E$ in growth and reproduction of animals still forms the subject of discussion (Ewan et al., 1969). Greater concentrations of Se in the organs of autumn voles may be connected with the slower rate of development of these voles as compared with spring individuals (Malzahn \& Lang, 1980). Least is known about the role of $\mathrm{Sb}$ in the organism, this being limited to finding its occurrence in a large number of mammal tissues and organs (Kost: et al., 1977), and in mitochondria and nuclein acids obtained from phyJogenetically different sources, in which it occurred in uniform concentrations (Girardi et al., 1977). This element and its compounds are accumulated in kidneys (Perry et al., 1973) and are considered as toxic to man.

Among type II trace elements the effect of $\mathrm{Zn}$ on the organism is known as that of an element essential to health and growth in animals, and is particularly connected with somatic growth, skin keratinization, osteogenesis, and also with the development and functions of the seminal glands in mammals (Underwood, 1962). This last role of $\mathrm{Zn}$ suggests that this element is connected with the more rapid sexual development and greater fecundity of spring generation voles as compared with those of the autumn generation (inter alia, Zejda, 1971). It was observed that when pure $\mathrm{Zn}$ was administered in combination with $\mathrm{Fe}$ to human patients, acceleration of rate of growth and sexual development took place (Davies, 1977). The fact is remarkable that $\mathrm{Zn}$ increases the effect of the antidiuretic hormone, which leads to water being retained in the tissues and reduction of the proportion of dry mass in such tissues ( $\mathrm{S}_{0}-$ roka \& Anisimova, 1974).

Little is known so far about the role in the organism of Eu, which is characterized by the greatest variations in concentration in vole o:gans. As an element of rare soils, to which Ce also belongs, it exhibits only a slight tendency to formation of complex compounds and thus does not occur in biologically active organic compounds in living o:ganisms. Possibly $\mathrm{Eu}$ and $\mathrm{Ce}$, like several other lanthanides, play in important part in calcium and sodium metabolism in the organisn (Alnaes \& Rahamimoff, 1974), accelerating the conduction of nerve inpulses (Metral et al., 1978). Eu concentrations in mitochondria and niclein acids, obtained from diverse biological material, do not differ from 
each other, like Sb concentrations (Girardi at al., 1977). Ce is considered as an element toxic to man, acting unfavourably on metabolic processes (D'Agostino at al., 1976). At this stage of our knowledge of the part played by the above elements in the organism it is as yet impossible to account for such great differences in the concentration of lanthanides in the organs of voles from the two study generations.

The role of Sc in the organism is also unknown, apart from finding it to occur in the kidneys and heart of white rats (Kostic et al., 1977), and in the livers of wild ungulates (Turkstra et al., 1977). In the bank vole it was also found to occur in the kidneys and heart; in concentrations greater in the organs of autumn generation voles than those of the spring generation (type I). Another element found sporadically, $\mathrm{Cr}$ (type II) occurs in kidneys in concentrations greater in spring than in autumn generation voles, and decreases with age. Chromium occurs in large amounts in RNA (Warren et al., 1959) and plays an important part in the metabolism of glucose, certain proteins and fats (Horvath, 1972). $\mathrm{Hg}$, on the other hand, is not a component essential to normal functioning of the organism and causes disturbance of metabolic processes. The contents of this metal in animal organs, particularly in the liver and kidneys, indicates the level of environment pollution by mercury.

The results obtained do not permit of analyzing the effect of the voles' food on concentrations of trace elements in their organs, since the voles examined did not differ in respect of quality and quantity of food to the same degree as voles living under natural conditions (Gębczyńska, 1976). Only the parental generation of the study voles had fed on natural food in the area, which may have affected accumulation of trace elements in the organs of young voles even during the prenatal period of their development.

Characteristic and very distinct differences occur in the variations in oxidation-reduction activity of organs in the voles of the generations compared during postnatal development. Spring voles have greater activity in the organs after birth, but are characterized by the quicker rate at which they attain the activity level of the organs proper to adult individuals, than is the case with autumn voles. This suggests that in voles there are extreme generations of seasonal differences in the physiological age of the animals of the same calendar age. Such differences have been found previously in respect of contents of the basic components of the voles' body, when individuals born in spring had a different chemical body composition as early as the day of their birth, from that of young voles born in autumn (Fedyk, 1974). Chemical maturity, that is, stabilization of the level of percentages of water, protein and mineral 
substances in the fat-free body mass of the organism, was attained by spring voles at the age of 35-40 days, but not until the age of $110-120$ days in the case of autumn generation voles. Tissue metabolism also (Gębczyński, 1977) and the mitotic index of epithelial tissues (Amstislavskaja, 1970) of voles born in spring was higher than in voles born in autumn. The slackening of correlation connections of the morphological and physiological indices of vole organs found in this study occurs to different degrees in voles of the two generations after the 30 th day of life.

Seasonal generations of the bank vole play an important part in maintenance of the biological continuity of the species (Petrusewicz et al., 1969/70). In a natural population of animals it is possible to observe the mechanism of regulation of the ageing process. The physiological growth and development of spring generation voles is correlated with their calendar age. The physiological growth of autumn generation voles in separate periods of the life cycle does not correspond to the chronological increase in age. In such voles, there is reduction in basic metabolism and the development of age changes is inhibited parallel to a change in habitat conditions, such as a drop in temperature or a change in natural food. The wide range of the rapidity with which the ageing process takes place in different individuals of the bank vole suggests that this process can be regulated.

\section{REFERENCES}

1. Alnaes E. \& Rahamimoff R., 1974: Dual action of praseodymium $\left(\operatorname{Pr}^{3+}\right)$ on transmitter relase at the frog neuromuscular synapse. Nature, 247: 478--479.

2. Amstislavskaja T. S., 1970: Dinamika mitotičeskoj aktivnosti $\mathrm{v}$ pokrovnyh tkaniah polevki Clethrionomys glareolus raznyh sezonnyh generacji. Ekologija, 4: $68-74$.

3. D'Agostino R., Olson F. S., Stineman C. H. \& Massaro E. J., 1976: Behavioral, developmental and general toxicologic effects of cerium in the mouse. Trace Subst. Env. Health, 10: 475-480.

4. Davies I. J. T., 1977: Medical significance of the essential biological metals. J. Radioanal. Chem., 37: 39-64.

5. Ewan R. C., Wastell M. E., Bicknell E. J. \& Speer V. C., 1969: Performance and deficiency symptoms of young pigs fed diets low in vitamin $E$ and selenium. J. Anim. Sci., 29: 912-915.

6. Fedyk A., 1974: Gross body composition in postnatal development of the bank vole. II. Differentiation of seasonal generations. Acta theriol., 19: 403-427.

7. Gębczyńska Z., 1976: Food habits of the bank vole and phenological phases of plants in an oak hornbeam forest. Acta theriol., 21: 223-236.

8. Gębczyński M., 1975: Heat economy and the energy cost of growth in the bank vole during the first month of postnatal life. Acta theriol., 20: 379-434.

9. Gębczyński M., 1977: Postnatal changes in tissue respiration of bank voles born in different season. Bull. Acad. Polon. Sci., Cl. II, 25: 405-409. 
10. Girardi F., Marafante E., Pietra R., Sabbioni E. \& Marchesini A., 1977: Application of neutron activation analysis to metallobiochemistry. J. Radioanal. Chem., 37: $427-440$.

11. Horvath D. J., 1972: An overview of soil/plant/animal relationships with respect to utilization of trace elements. Annals New York Academy of Sciences, 2: 82-94.

12. Jakutowicz K., 1973: Zastosowanie analizy aktywacyjnej w. badaniach medycznych na przykładzie niektórych pasożytów. Post. Fiz. Med., 8, 1-2: 109--117 .

13. Jemielianov I. G., 1976: Izučenije otnositelnogo rosta nekotoryh vnutrennyh organov obščestvennyh polevok populacii celinnoj stepi Askania Nova. Vestnik Zool., 3: 14-19.

14. Kaczmarski F., 1966: Bioenergetios of pregnancy and lactation in the bank vole. Acta theriol., 11: 409-417.

15. Kostić K., Draškovi“ R. J., Ratković M., Kostić D. \& Drašković R. S., 1977: Determination of some trace elements in different organs of normal rats. J. Radioanal. Chem., 37: 405-413.

16. Malzahn E., 1978: The oxidation-reduction activity of organs in Sorex araneus Linnaeus, 1758. Comp. Biochem. Physiol., 62 A: 909-913.

17. Malzahn E. \& Lang B., 1980: Age variation of selenium distribution in

- Clethrionomys glareolus as depending upon its natal season. Comp. Biochem. Physiol., 67 B: 257-260.

18. Maugh II T. H., 1.973: Trace elements: a growing appreciation of their effects of man. Science, 181: 253-264.

19. Metral S., Bonneton C., Hort-Legrand C. \& Reynes J., 1978: Dual action erbium in transmitter relase at the frog neuromuscular synapse. Nature, 271: $773-775$.

20. Pearson A. M., 1962: Activity patterns, energy metabolism, and growth rate of the voles Clethrionomys rufocanus and C. glareolus in Finland. Ann. Soc. zool.-bot. fenn. Vanamo, 24: 1-58.

21. Perry H. M., Perry E. F., Purifoy J. E. \& Erlanger J. N., 1973: A comparison of intra- and interhepatic variability of trace metal concentrations in normal men. Trace Subst. Env. Health, 7: 281-288.

22. Petrusewicz K., Andrzejewski R., Bujalska G. \& Gliwicz J., 1969/70: The role of spring, summer and autumn generations in the productivity of a free-living population of Clethrionomys glareolus. [In: Energy flow through small mammal populations. Eds. K. Petrusewicz \& L. Ryszkowski] PWN: 235-245, Warsaw.

23. Soroka V. R. \& Anisimova V. P., 1974: Vlijanije form himičeskoj sviazi cinka na aktivnost nukleaz, biosintez nukleinovyh kislot i raztvorimogo bielka $\mathrm{v}$ tkaniah životnyh. [In: Mikroelementy v medicinie]: 114-119, Kijev.

24. Sviridenko P. A., 1959: Rost i razvitije evropejskoj ryžej polevki (Clethrinomys glareolus Schreb.). Zool. Ž., 38: 756-766.

25. Turkstra J., Harthoorn A. M., Benkes P. J. L. \& Brits R. J. N., 1977: The influence of seasonal changes in the concentration of trace elements in liver tissue of various wild animals determined by instrumental neutron activation analysis. J. Radioanal. Chem., 37: 473-481.

26. Tipton I. H. \& Cook M. J., 1961: [In: Trace elements in human and animal nutrition E. J. Underwood.] Academic Press, 1962, New York and London.

27. Underwood E. J., 1962: Trace elements in human and animal nutrition. Academic Press: $1-429$, New York and London. 
28. Underwood E. J., 1971: Trace elements in human and animal nutrition. Academic Press: 1-543, New York.

29. Warren E., Wacker C. \& Vallee B. L., 1959: Nucleic acids and metals. I. Chromium, manganese, nickel, iron and other metals in ribonucleic acid from diverse biological sources. J. Biol. Chem., 234: 3257-3262.

30. Zejda J., 1971: Differential growth of three cohorts of the bank vole, Clethrionomys glareolus, Schreb., 1780. Zool. Listy, 20: 229-245.

Accepted, November 23, 1981.

\section{Elżbieta MALZAHN}

\section{PIERWIASTKI SLADOWE I ICH ZNACZENIE W ROZWOJU POSTNATALNYM SEZONOWYCH GENERACJI NORNICY RUDEJ}

\section{Streszczenie}

Zmierzono koncentracje 10 pierwiastków śladowych (Fe, $\mathrm{Zn}, \mathrm{Co}, \mathrm{Se}, \mathrm{Sb}, \mathrm{Eu}$, $\mathrm{Cr}, \mathrm{Hg}, \mathrm{Sc}$ i Ce) w aktywnych metabolicznie organach (wątroba, nerki i serce) nornicy rudej Clethrionomys glareolus (Schreber, 1780) w ciągu pierwszych dwóch miesięcy jej życia (Tabela 3) metodą instrumentalnej neutronowej analizy aktywacyjnej (Tabela 1). Do badań użyto 456 nornic $w$ siedmiu grupach wiekowych (1, 10, 20, 30, 60, 90 i 120 dni życia) ze skrajnych generacji sezonowych - wiosennej i jesiennej, otrzymanych od rodziców odłowionych w Białowieskim Parku Narodowym w latach 1975 i 1976 (Tabela 2). Obliczono całkowitą zawartość poszczególnych pierwiastków w suchej masie wątroby (Ryc. 1), nerek (Ryc. 2) i serca (Ryc. 3) nornic obu generacji w trakcie rozwoju postnatalnego. Największe średnie zawartości większości pierwiastków w organach nornic występują w wątrobie, a najmniejsze w sercu (Ryc. 4). Wyróżniono dwa typy pierwiastków, różniące się zawartością w organach nornic porównywanych generacji: $\mathrm{Fe}, \mathrm{Co}, \mathrm{Se}, \mathrm{Sb}$ i Sc (typ I) zawierały więcej organy nornic generacji jesiennej niż wiosennej, natomiast $\mathrm{Eu}, \mathrm{Zn} \mathrm{i} \mathrm{Cr} \mathrm{(typ} \mathrm{II)} \mathrm{zawierały} \mathrm{więcej} \mathrm{organy} \mathrm{nornic} \mathrm{generacji} \mathrm{wiosennej} \mathrm{niż} \mathrm{je-}$ siennej w każdej grupie wiekowej.

Zmienność koncentracji pierwiastków śladowych w organach nornic $w$ trakcie jch rozwoju jest podobna do zmienności aktywności oksydoredukcyjnej organów badanej metodą chemiluminescencyjną (Tabela 4, Ryc. 5). Przy pomocy inaktywacji chemicznej i termicznej uzyskano informacje o dużym wpływie substancji nieorganicznych na poziom aktywności oksydoredukcyjnej organów (Tabela 5). Stwierdzono istotną ujemną korelację między ciężarami organów a ich aktywnością $u$ nornic obu generacji w całym badanym okresie rozwoju (1-120 dni $\dot{z} y c i a)$, zmniejszającą się wraz z wiekiem zwierząt (Ryc. 6).

Maksymalną aktywnością, pcdobnie jak maksymalną koncentracją pierwiastków śladowych charakteryzują się nornice obu generacji w wieku 1-go lub 10-ciu dni, po czym występuje zmniejszanie się obu wskaźników do 30-go dnia życia nornic. W późniejszym wieku aktywność organów ulega dalszemu obniżeniu aż do ustalenia się niskiego jej poziomu, charakterystycznego dla osobników dorosłych. Nornice generacji wiosennej mają wyższy poziom aktywności organów po urodzeniu, ale szybciej osiągają niski poziom aktywności organów niż nornice generacji jesiennej. Zmienność uzyskanych wskaźników analizowano $w$ aspekcie mechanizmów starzenia się osobników pochodzących z różnych generacji sezonowych nornicy rudej. 